\title{
Colostrum from Different Animal Species - A Product for Health Status Enhancement
}

\author{
Mirela AHMADI ${ }^{1}$, Oana BOLDURA ${ }^{1}$, Cornelia MILOVANOV' ${ }^{1}$, Dorel DRONCA*2, Călin MIRCU ${ }^{1}$, Ioan HUŢU ${ }^{1}$, \\ Sorina POPESCU ${ }^{3}$, Ioan PĂDEANU ${ }^{2}$ and Camelia TULCAN ${ }^{1}$ \\ ${ }^{1}$ Faculty of Veterinary Medicine, University of Agricultural Sciences and Veterinary Medicine "King \\ Mihai 1" of Banat Timisoara, Romania (USAMVB), Calea Aradului 119, Timisoara 300645, Romania; \\ ${ }^{2}$ Faculty of Animal Science and Biotechnologies, USAMVB \\ ${ }^{3}$ Faculty of Horticulture and Forestry, USAMVB \\ *Corresponding authors, e-mail: ddronca@animalsci-tm.ro
}

Bulletin UASVM Animal Science and Biotechnologies 73(1)/ 2016

Print ISSN 1843-5262; Electronic ISSN 1843-536X

DOI:10.15835/buasvmcn-asb: 11949

\begin{abstract}
The first milk after birth is also known as colostrum. The composition of animal and human colostrum depends very much on different factors such as: animal species, animal breed and genetical characteristics, feeding program, diet. Bovine colostrum is used in different therapies due to its composition in nutraceuticals, but also because the cow gives high quantity colostrum compared to other animal species (goats or ewes). The immunological properties of colostrum are acknowledged in various studies. Due to its immunoglobiline content, it is an alternative therapy in immunity enhancement. Colostrum is also used in athletes' supplementation plan with very good results in their competition performance. Dry matter composition of cow, goat and ewe's colostrum can give very good information about the nutritional composition, especially proteins. Thus, proteins, lipids, minerals, vitamins are significantly higher in colostrum right after parturition and decrease very much in time in mature milk. Lactose - in most of the studies - presents an increase in concentration from colostrum to milk. Our study reflects the highest content of dry matter in ewe colostrum, with significant decrease in goat and cow. Total lipid content was highest also in ewe's colostrum, lower in cow's, and the lowest in goat colostrum. In most samples, minerals (copper, manganese, zinc) had - the highest concentration in colostrum milking with a decrese from the 6 hour colostrum to the 48 hour colostrum collected after parturition. Iron composition increases in ewe colostrum from the 6 hours to 48 hours.
\end{abstract}

Keywords: colostrum, health enhancement

\section{INTRODUCTION}

Colostrum is considered "the first raw milk" after parturition, and it varies very much in nutrients depending of the animal species and breed, because of feeding and genetic characteristics. Thus, due to multivariate feeding plants, the goat colostrum should have the best nutrient composition, compared to bovine or sheep colostrum, but even this depends on the feeding plan (concentrated dry feed or fodder) (Ahmadi-Vincu et al., 2005; Ruiz et al., 2014; Sanchez-Macias et al., 2015; Alves et al., 2015).
The aim of this study was to associate the nutritional composition of colostrum from different species of animals with the enhancement of the immunity system.

Colostrum is the secretion of the mammary gland of animals and humans in the first 48 hours after parturition. The nutraceutical components of colostrum are represented in principal by immune and growth factors; at the same time, the composition in amino acids, total proteins, enzymes, fatty acids, total lipids, hormones, vitamins, minerals is very important 
for mammalian neonates. One of the main effects of colostrum on newborn babies is its laxative action, which helps in meconium evacuation (first stool) and it also helps in excretion of excessive bilirubin for prevention of icterus. Due to the immunoproteins in its composition, colostrum protects infants from infections.

The supplements based on bovine colostrum have been proved to lead to improved performance in athletes. Thus, Shing and his collaborators in 2006 studied the influence of administration of bovine colostrum supplements (in low dose) to cyclists for 10 weeks of exercise activity, including five days of high intensity training. The results demonstrated that bovine colostrum supplementation in cyclists' performance presented improvements in $40-\mathrm{km}$ trials, and increased the time trial intensity while maintaining the same heart rate.

The colostral nutraceutical components vary across animal species compared to human, but also the breed is very important. Animal improvement methods have in view even the production of milk, and for sure this is also connected to animal colostrum production (Dronca, 2007). In table 1 we presented a collection of literature review data of general nutrients from colostrum in different animal species (Banchero et al., 2004; Csapo et al., 2008; Eddleman, 2005; Hadjipanayiotou, 1995; Martini et al., 2012; Sustova et al., 2007; Vatankhah, 2013).

Struff and Sprotte reported in 2008 that bovine colostrum - due to its composition - can be used in clinical trials for its antibacterial effect and for modulation of the immune response in human patients. Their research demonstrated in therapy on animal models that bovine colostrum concentrates have the ability to neutralize lipopolysaccharides such as endotoxins formed by pathogen Gram-negative bacteria, and also have the ability to inhibit enterogenic endotoxemia. Thus, Struff and Sprotte reported that oral administration of bovine colostrum concentrates reduce the influx of lipopolysaccharides, which seems to be the main mechanism in Gram-negative septic shock.

Total dry matter decreases very much in time. In ewes, the total solids are lower on day three $(17.32 \%)$ compared to the first six hours after parturition (24.58). Lactose concentration on day three ewe colostrum was $3.74 \%$ and in the $12^{\text {th }}$ week after parturition lactose content increased to $4.30 \%$. The ash-mineral composition in ewe's milk was $0.65 \%$ in the second week of lactation. The total protein from ewe's milk in the $12^{\text {th }}$ week after birth was 5.33\% (Oguike and Udeh, 2008). One reson for this could be the quantity of colostrum from ewes compared to other species and baby's needs. Ewes secreted less colostrum and milk compared to goats or cows. The quantity of colostrum that feeds the lamb has to provide the optimal nutrients - so ewe's colostrum contains high dry matter and nutrients compared to that of other studied animal species or to human colostrum.

Thus, goat colostrum seems to have the highest quality in retinols and tocoferols, but also in iron, compared to bovine and sheep colostrum. Concentration in immunoproteins (IgA, IgG, IgM), lactoferine, proline rich peptides, other high quality proteins, essential enzymes, minerals ( $\mathrm{Fe}$, $\mathrm{K}, \mathrm{Ca}, \mathrm{Mg}, \mathrm{Cu}, \mathrm{Zn}$ and others) is much higher in the first hours after parturition, and decreases and varies a lot in time, once colostrum turns into mature milk. Also, the concentration in other nutrients, such as vitamins, lipids and lactose is different in colostrum as compared to mature milk.

The nnutrients composition of colostrum leads to enhanced immunity, sickness recovery (such as flu), allergy relief, Alzheimer and asthma

Tab 1. Colostrum nutrient composition in various animal species (mean of first 6 hours after parturition - \%)

\begin{tabular}{|c|c|c|c|c|c|c|c|}
\hline Specification & $\begin{array}{c}\text { Measure } \\
\text { Unit }\end{array}$ & $\begin{array}{c}\text { Total } \\
\text { Proteins } \\
\end{array}$ & Casein & $\begin{array}{c}\text { Lactose - } \\
\text { carbohydrates } \\
\end{array}$ & $\begin{array}{c}\text { Total } \\
\text { Lipids }\end{array}$ & $\begin{array}{l}\text { Ash - } \\
\text { mineral content }\end{array}$ & $\begin{array}{c}\text { Dry } \\
\text { matter }\end{array}$ \\
\hline Bovine colostrum & \multirow{4}{*}{$\%$} & 3.3 & 2.68 & 4.8 & 3.8 & 0.71 & 12.8 \\
\hline Ewe (sheep) colostrum & & 6.35 & 4.82 & 3.23 & 8.21 & 0.59 & 24.58 \\
\hline Goat colostrum & & 3.4 & 1.94 & 4.7 & 4.1 & 0.77 & 13.0 \\
\hline Human colostrum & & 1.2 & 0.5 & 7.0 & 3.8 & 0.21 & 12.4 \\
\hline
\end{tabular}


support; it is useful in anti-aging prevention and treatment; it is effective in oxidative stress protection; it is very good for athletes as natural supplement for growth and improvement of lean muscle, sprint capacity, in muscle recovery after intense effort, and it is completely legal to use.

\section{MATERIALS AND METHODS}

The first step in this study was to collect the colostrum from different animal species: goat, sheep, and bovine (cow) from Timis county (Romania). For mineral determinations, we used the Atomic Absorption Spectrometry (AAS) method. Bovine's (cow) colostrum was collected from Bălţată Românească breed, ewe's (sheep) colostrum was collected from Tुurcană breed, and goat's colostrum was collected from Carpatină breed. We sampled the colostrum in the first hour after parturition, and at six hours, twentyfour hours, and forty-eight hours after birth. The animals were fed ad libitum with grass silage, and with concentrates or hay and had water from the home system. Also, the animals were not given nutritional supplements before parturition. We collected five colostrum samples from five different animals and for every animal species, and we calculated the mean and standard deviation as presented in this article.

For proper hygiene, just before collecting colostrum samples, we washed the udder of every animal with wather several times and dried it using paper towels. The colostrum samples were stored in clean and dry sterile containers, and were transported in refrigeration conditions to the laboratory where we froze the samples until analysis. Before analysis, we warmed up the colostrum samples in warm water to approximately $37^{\circ} \mathrm{C}$ (Bain-Marie system) and then we homogenised the colostrum for composition uniformity. With the AAS method we digested the colostrum and prepared the solutions for analyses of copper, manganese and iron, but we analysed also the dry matter with SR EN ISO $1737: 2001$ method (dry at $103^{\circ} \mathrm{C} \pm 2^{\circ} \mathrm{C}$ ) and total lipid content with SR EN ISO 1737:2001 method (Gerber method).

\section{RESULTS AND DISCUSSION}

Most of the nutrients are highly concentrated in the first hours after parturition, with severe decrease hour by hour, with the exception of lactose
Table 1. Lipids and dry matter content of cow, ewe and goat colostrum [\%]

\begin{tabular}{ccc}
\hline \multirow{2}{*}{ Specification } & Lipids [\%] & Dry matter [\%] \\
\cline { 2 - 3 } & $\overline{\mathrm{x}} \pm \mathrm{SD}$ & $\mathrm{x} \pm \mathrm{SD}$ \\
\hline Cow & $5.65 \pm 0.26$ & $12.03 \pm 0.20$ \\
\hline Ewe & $9.11 \pm 0.27$ & $21.32 \pm 0.51$ \\
\hline Goat & $4.88 \pm 0.22$ & $13.68 \pm 0.80$ \\
\hline
\end{tabular}

- that has low concentration in the first colostrum as compared to late colostrum or mature milk. On the other hand, colostrum composition depends on the animal species, the feeding programme / diet, breed, quantity of the secreted colostrum, and - according to several reports on research on the number of births for every animal.

Total lipid concentration in colostrum presented significant variations at 6 hours after birth depending on the animal species, as presented in table 1.

Ewe (sheep) colostrum, concentration of lipids and dry matter presented the highest values compared to goat and cow, maybe because the quantity of sheep colostrum is lower than that of goat or cow. Also, the total solids depend very much on the animal species, varying from $21.32 \%$ in ewe's colostrum to $12.03 \%$ in cow's colostrum, while the lipid composition varies from $9.11 \%$ in ewe's colostrum to $4.88 \%$ in goat's colostrum.

Minerals are present in higher concentration in colostrum compared to milk for all animal species and for humans. Research studies on sheep colostrum indicated an increase of sodium and iron concentration in the first 72 hours, while the concentration of magnesium, calcium, potassium, zinc decreases significantly from the first day after parturition to the $12^{\text {th }}$ day (Goran et al., 2010). Lactoferrin concentration in goat colostrum and milk presents various values depending even on breed. So, the Saanen goats crosses with Peranakan etawah goat presented the highest concentration of lactoferrin - $207 \mathrm{mg} / \mathrm{l}$, then Jawarandu goat crosses with Peranakan etawah had 197mg/l, and Peranakan etawah goat breed had 156mg/l lactoferrin in the first day of lactation after birth. On the $8^{\text {th }}$ day of goat lactation after parturition the lactoferin decreased significantly by 73 to $85 \%$ (Rachman et al., 2015).

Lipid concentration of colostrum compared to milk depends very much on the animal species. 
Thus, the lipid content of bovine, sheep, goat, swine and horse colostrum is significantly higher than in milk, but the content of lipid from camel colostrum is lower compared to milk (Zhang et al., 2005; Ahmadi et al., 2009; Shrinivas et al., 2010; Pandey et al., 2011; Marounek et al., 2012; Alves et al., 2015). Fatty acids present in samples from goat colostrum were made up of $67 \%$ saturated fatty acids, $28.2 \%$ monounsaturated fatty acids, and $4.4 \%$ polyunsaturated fatty acids (percent from thirty-eight determined fatty acids in colostrum and milk fat). The highest concentration of fatty acids was represented by palmitic, oleic, stearic, and myristic acids both in colostrum and in 30-day milk in White Shorthaired goat on a winter diet in the Czech Republic. Similarly, the concentration of palmitic and myristic acids was higher in colostrum samples compared to the 30-day goat milk samples. Concentration of capric acid, stearic acid and oleic acid increased in mature goat milk compared to goat colostrum (Marounek et al., 2012).

We also analysed the concentration of cooper, manganese, iron and zinc from ewe's, goat's and cow's colostrum at 6,24 and 48 hours after parturition. The concentration of minerals was given in ppm and the obtained data are presented in table 2.

The AAS analysis of some mineral composition of colostrum revealed the highest concentration of zinc, followed by manganese, then iron and copper. Copper concentration also presented a decrease in all samples from $2.34 \mathrm{ppm}$ to 1.81 $\mathrm{ppm}$ in cow colostrum; from $1.98 \mathrm{ppm}$ to $1.03 \mathrm{ppm}$ in goat colostrum, and an increase in ewe colostrum from 1.42ppm to 1.48ppm. Manganese concentration decreased in cow colostrum from $5.59 \mathrm{ppm}$ to $5.01 \mathrm{ppm}$; from $6.33 \mathrm{ppm}$ to $3.43 \mathrm{ppm}$ in ewe colostrum; and from $4.72 \mathrm{ppm}$ to 4.27 in goat colostrum. Iron concentration presented the highest concentration in ewe colostrum 6 hours after birth (5.47ppm), which incresed to $6.34 \mathrm{ppm}$ at 48 hours; iron concentration was $2.99 \mathrm{ppm}$ in goat colostrum and decreased to $2.56 \mathrm{ppm}$ two days after parturition; cow colostrum presented a variation from $1.95 \mathrm{ppm}$ to $1.31 \mathrm{ppm}$. Zinc concentration decreases from $15.56 \mathrm{ppm}$ to $7.99 \mathrm{ppm}$ in cow colostrum; from $9.57 \mathrm{ppm}$ to $8.61 \mathrm{ppm}$ in ewe colostrum; zinc concentration decreases from $7.05 \mathrm{ppm}$ to $5.67 \mathrm{ppm}$ in goat colostrum 48 hours after parturition.

Kramski and his team (in 2012) presented in a research article that from each immunised cow, right after calving, we can collect about $0.5 \mathrm{Kg} / \mathrm{l}$ of immunoglobilines from bovine colostrum. They administrated a modified vaccination plan (pre- and/or post-conception) to cows in order to establish a method to produce HIV-1 neutralizing IgG on a large-scale. Their results demonstrated that obtaining anti-HIV antibodies from bovine colostrum concentrates is a low-cost and effective alternative to obtain

Table 2. Concentration of $\mathrm{Cu}, \mathrm{Mn}, \mathrm{Zn}, \mathrm{Fe}$ from colostrum collected from sheep, goat and bovine at 6, 24 and 48 hours after birth [ppm]

\begin{tabular}{ccccc}
\hline \multirow{2}{*}{ Specification } & $\mathrm{Cu}[\mathrm{ppm}]$ & $\mathrm{Mn}[\mathrm{ppm}]$ & $\mathrm{Fe}[\mathrm{ppm}]$ & $\mathrm{Zn}[\mathrm{ppm}]$ \\
\cline { 2 - 5 } & $\overline{\mathrm{x}} \pm \mathrm{SD}$ & $\mathrm{x} \pm \mathrm{SD}$ & $\overline{\mathrm{X}} \pm \mathrm{SD}$ & $\mathrm{x} \pm \mathrm{SD}$ \\
\hline 6 hours & & & & \\
\hline Cow & $2.34 \pm 0.10$ & $5.59 \pm 0.14$ & $1.95 \pm 0.11$ & $15.56 \pm 0.14$ \\
\hline Ewe & $1.42 \pm 0.09$ & $6.33 \pm 0.27$ & $5.47 \pm 0.11$ & $9.57 \pm 0.23$ \\
\hline Goat & $1.98 \pm 0.16$ & $4.72 \pm 0.23$ & $2.99 \pm 0.21$ & $7.05 \pm 0.28$ \\
\hline 24 hours & & & & \\
\hline Cow & $1.94 \pm 0.23$ & $5.24 \pm 0.31$ & $1.45 \pm 0.09$ & $6.87 \pm 0.23$ \\
\hline Ewe & $1.24 \pm 0.16$ & $5.65 \pm 0.21$ & $5.98 \pm 0.12$ & $9.12 \pm 0.30$ \\
\hline Goat & $1.85 \pm 0.08$ & $4.31 \pm 0.21$ & $2.67 \pm 0.12$ & $6.78 \pm 0.16$ \\
\hline 48 hours & & & & \\
\hline Cow & $1.81 \pm 0.10$ & $5.01 \pm 0.18$ & $1.31 \pm 0.11$ & $7.99 \pm 0.29$ \\
\hline Ewe & $1.48 \pm 0.12$ & $3.43 \pm 0.09$ & $6.34 \pm 0.15$ & $8.61 \pm 0.13$ \\
\hline Goat & $1.03 \pm 0.12$ & $4.27 \pm 0.14$ & $2.56 \pm 0.08$ & $5.67 \pm 0.15$ \\
\hline
\end{tabular}


broadly neutralising antibodies needed as HIV-1 microbicide.

Baddour used bovine colostrum treatment with good results as a nonantibiotic primary or alternative therapy in prevention of Clostridium difficile infection in piglets - which is the principal cause of morbidity and even mortality in older patients (2014).

Protein and immunoglobulin composition of colostrum from most of animal species is significantly increased right after calving compared to milk composition. Amino acids and protein content from bovine colostrum were presented in studies by Ray Sarkar et al. even as early as 1949. The researchers presented the variation of amino acids in the colostrum of Jersey and Holstein cows (as mean) taken one hour and 24 hours from calving, and also from milk taken in the 60 days and 90 days after calving. However, the concentration of Leucine, Isoleucine, Histidine and Methionine increased in milk compared with both samples of colostrum (with $4 \%$ to 38\%), but the content of Valine, Phenylalanine, Arginine, Threonine, Tryptophan and Lysine decreased in milk compared to colostrum by $35 \%$ to $3 \%$.

Infants need immunoglobulins (Ig) that ensure the specific antimicrobial activity such as IgA, IgD, IgE, IgG (assure protection to prevent infections), IgM (assure the good functioning of internal membranes such as intestinal mucosa) (Thapa, 2005). Immunoglobulins are transferred right after parturition from colostrum to the newborn for animals such as bovine, goat, ovine, equine; while for humans immunoglobulins are transferred via the placenta to the newborn baby right after birth (Muller and Ellinger, 1981 citated by Pandey et al., 2011; Stelwagen et al., 2008).

However, the optimum absorbtion of immunoglobulins occurs in the first four hours and decreases very much at twelve hours after birth (Vasseur et al., 2010).

Because of immunoglobulin absorption and immunological properties, the first meal is very important for newborn lambs and for infants' health in all animal species (HernandezCastellano et al., 2015).

The most important hormones from colostrum are growth factors such as: growth hormon and growth hormone releasing factor, epidermal growth factor, transforming growth factor a and b, insulin such as growth factor, platelet derived growth factor, vascular endothelial growth factor. Also, after parturition colostrum contains calcitonine, luteinising hormone releasing factor, oxytocin, prolactine, somatostatin, estrogen, progesterone, thyroid stimulating hormone, and thyroxine (Shrinivas et al., 2010).

The main enzymes present in colostrum are a-amylase, lactoperoxydase, protease and protease inhibitor.

Colostrum is very rich in b-caroten (yellow coloure of colostrum is also due carotene concentration), and retinols, cobalamin, B vitamins, ascorbic acid and tocopherols.

\section{CONCLUSION}

Colostrum composition depends on the animals species, the breed and genetical characteristics, diet and feed plan, and also on the time of milking after parturition.

Ewe's colostrum is the highest in total solids or dry matter compared to goat and cow, which could also be explained by the quantity of colostrum secreted by sheep compared to goat and bovine. Total lipids from colostrum was $9.11 \%$ for ewe's colostrum and decresed to $5.65 \%$ for cow colostrum, and to $4.88 \%$ for goat colostrum.

The mineral composition of colostrum depends on the time of milking after parturition, but also on the animal species (sheep, goat and bovine). The Atomic Absorption Spectroscopy quantitative analysis of four mineral composition in colostrum presented the highest concentration of zinc, followed by concentration of manganese, iron and copper.

Zinc concentration decreases by $48.78 \%$ in cow colostrum; by $10.03 \%$ in ewe colostrum; zinc concentration decreased by $19.57 \%$ in goat colostrum 48 hours after parturition. Manganese concentration decreased in cow colostrum by $10.37 \%$; by $45.81 \%$ in ewe colostrum; and by $9.53 \%$ in goat colostrum. Copper concentration also presented a decrease in all samples by $22.64 \%$ in cow colostrum; $47.97 \%$ in goat colostrum and increased in ewe colostrum by $4.22 \%$. Iron concentration presented the highest concentration in ewe colostrum 6 hours after birth $(5.47 \mathrm{ppm})$, which increased by $15.90 \%$ at 
48 hours; iron concentration in goat colostrum decreased by $14.38 \%$ two days after parturition; and cow colostrum presented a decrease by $32.82 \%$ from the 6 hour milking to the 48 hour milking of colostrum after parturition.

\section{REFERENCES}

1. Ahmadi $M$, Velciov A, Riviş A, Traşcă T, Hărmănescu M, Antoanela C, Scurtu M (2009) Physico-chemical and Nutritional Characterization of Bovine Colostrum, pp. 430$433,16^{\text {th }}$ Symposium on Analytical and Environmental Problems, SZAB Szeged, Hungary, 28 september 2009.

2. Ahmadi-Vincu M, Ahmadi T, Ahmadi J (2005) Colostrum as nutritional supplement in sport, Symposium Scientifical Researches Agroalimentary Processes And Technologies - Safe food al over Europe”, Universitatea „S.A.M.V.B.” Timişoara, Ed. „Agroprint” Timisoara, ISSN 1453-1399, XI(1), 33-40.

3. Alves AC, Alves NG, Ascari IJ, Junqueira FB, Coutinho AS, Lima RR, Perez JRO, De Paula SO, Furusho-Garcia IF, Abreu LR (2015). Colostrum composition of Santa Ines sheep and passive transfer of immunity to lambs, Journal of Dairy Sciences, 68(6): 3706-3716.

4. Banchero GE, Quintans G, Martin GB, Lindsay DR, Milton JT (2004). Nutrition and colostrum production in sheep. 1. Metabolic and hormonal responses to a high-energy supplement in the final stage of pregnancy, Reprod. Fertil. Dev., 16(6): 633-643.

5. Baddour LM (2014). Hyperimmune Bovine Colostrum for Treatment of CDI, J. Infec. Dis., Nov 7 - e-print.

6. Csapo J, Salamon S, Loki K, Csapo-Kiss Z (2008). Composition of mare's colostrum and milk II. Protein content, amino acid composition and contents of macroand micro-elements, Acta Univ. Sapientiae Alimentaria, 2(1): 133-148.

7. Dronca D (2007) Ameliorarea genetică a populaţiilor de animale, Ed. Mirton, Timişoara

8. Eddleman H (2005) Composition of Human, Cow and Goats milk, Internet (http://www.disknet.com/indiana_ biolab/b120a.htm).

9. Goran GV, Crivineanu V, Rotaru E, Tudoreanu L, Hanganu A (2010). Dynamics of some mineral elements in sheep colostrum, Buletin UASVM, Veterinary Medicine, 67(2): 81-87.

10. Hadjipanayiotou M (1995). Composition of ewe, goat and cow milk and of colostrum of ewes and goats, Small Ruminant Research, 18(3): 255-262.

11. Hernandez-Castellano LE, Morales-delaNuez A, SanchezMacias D, Moreno-Indias I, Torres A, Capote J, Arguello A, Castro N (2015) The effect of colostrum source (goat vs. sheep) and timing of the first colostrum feeding ( $2 \mathrm{~h}$ vs. $14 \mathrm{~h}$ after birth) on body weight and immune status of artificially reared newborn lambs, J. Dairy Sci., 98: 204210.

12. Kramski M, Center RJ, Wheatley AK, JacobsonJC, Alexander MR, Rawlin G, Purcell DFJ (2012). Hyperimmune Bovine Colostrum as a Low-Cost, Large-Scale Source of Antibodies with Broad Neutralizing Activity for HIV-1
Envelope with Potential Use in Microbicides, Antimicrob Agents Chemother., 56(8): 4310-4319.

13. Marounek M, Pavlata L, Misurova L, Volek Z, Dvorak R (2012) Changes in the Composition of Goat Colostrum During the First Month of Lactation, Czech J. Anim. Sci., 57(1): 28-33.

14. Martini M, Iolanda A, Salari F (2012). The lipid component of Massese ewe's colostrum: Morphometric characteristics of milk fat globules and fatty acid profile, Int. Dairy J., 24(2): 93-96.

15. Oguike MA, Udeh NE (2008). Influence of Spondias mombin I (hog plum) on colostrum, milk composition and growth in west African dwarf sheep, Animal Production Research Advances, 4(3-4)

16. Pandey NN, Dar AA, Mondal DB, Nagaraja L (2011). Bovine colostrum: A veterinary nutraceutical - Review, J Vet Med and Animal Health, 3(3): 31-35

17. Rachman AB, Maheswari RRA, Bachroem MS (2015). Composition and Isolation of Lactoferrin from Colostrum and Milk of Various Goad Breeds, Procedia Food Sciences, 3: 200-210.

18. Ray Sarkar BC, Luecke RW, Duncan CW, Ely RE, Watson GI, Rykala AJ (1949) The amino acid composition of bovine colostrum and milk, Official J American Dairy Sci Assoc, 32(7): 671-678

19. Ruiz P, Sesena S, Rieiro I, Llanos PM (2014). Effect of postpartum time and season on the physicochemical characteristics of Murciano-Granadina goat colostrum, Int. J. Diary Tech, 68(1): 88-96.

20. Sanchez-Macias D, Moreno-Indias I, Castro N, Moralesde la Nuez A, Argüello A (2015). From goat colostrum to milk: Physical, chemical, and immune evolution from partum to 90 days postpartum, J. Dairy Sci., 97:10-16.

21. Shing CM, Jenkins DG, Stevenson L, Coombes JS (2006) The influence of bovine colostrum supplementation on exercise performance in highly trained cyclists, Br. J. Sport Med., 40(9): 797-801

22. Shrinivas B, Rajesh P, Manisha S (2010) Colostrum: all in one Medicine - Review article, International Journal of Pharmacy and Pharmaceutical Sciences, 2(1): 31-36.

23. Stelwagen K, Carpenter E, Haigh B, Hodgkinson A, Wheeler TT (2008). Immune components of bovine colostrum and milk, J. Anim. Sci., 87(13-suppl.): 3-9

24. Struff WG, Sprotte G (2008). Bovine colostrum as a biologic in clinical medicine: a review - Part II: clinical studies, Int. J. Clin. Pharmacol. Ther., 46(5): 211-225.

25. Sustova K, Ruzickova J, Kuchtik J (2007). Application of FT near spectroscopy for determination of true protein and casein in milk, Czech J. Anim. Sci., 52(9): 284-291.

26. Thapa BR (2005) Health factors in colostrum, Indian J. Pediatr., 72(7): 579-581.

27. Vasseur E, Borderas F, Cue RI, Lefebvre D, Pellerin D, Rushen J, Wade KM, Passille AM (2010). A survey of dairy calf management practices in Canada that affect animal welfare, J. Dairy Sci., 93: 1307-1315

28. Vatankhah M (2013) Relationship between Immunoglobulin concentration in the ewe's serum and 
colostrum, and lamb's serum in Lori-Bakhtiari Sheep Iranian J. Applied Animal Sci., 3(3): 539-544
29. Zhang H, Yao J, Zhao D, Liu H, Li J, Guo M (2005). Changes in chemical compostion of Alxa Bactrian camel milk during lactation, J. Dairy Sci., 88: 3402-3410. 